\title{
Nyerere in the Eyes of his Critics
}

\author{
Ignas Fedeo
}

1 University of Dar es Salaam, Tanzania

${ }^{*}$ Correspondence: mwasongweignas@gmail.com

\begin{abstract}
There are a number of positive ideals about Mwalimu Julius Nyerere in the literatures. His ideals includes among others his devotion for peace, security, unity and democracy. However, the ideals do not limit the visibility of his negative traits. This paper specially examines the criticisms against Nyerere. The paper looks at the portrayal of Nyerere in number literatures from his critics. It examines the literatures against Nyerere in number of issues including his role in the decolonization struggle, the situation of democracy and individual freedom during his reign and his position towards Islamic religion and Zanzibar revolution. The paper establishes that most of criticisms against Nyerere are not refuted because supporters and critics talk about different things. Whereas his supporters put forward his role in building the nation, critics focus his in his economic failure and deprivation of individual freedom in Tanzania.
\end{abstract}

\section{ARTICLE HISTORY}

Published March $27^{\text {th }} 2021$

Check for updates

\section{KEYWORDS}

Nyerere, Criticisms, Tanzania, Islamic religion, Ujamaa

\section{ARTICLE LICENCE}

(C) 2021 Universitas Hasanuddin Under the license CC BY-SA 4.0

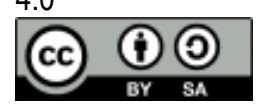

\section{Introduction}

Several ideals are associated with Mwalimu Julius Kambarage Nyerere, the first president and Tanzanian Father of the Nation. According to Mohiddin, Nyerere "was, certainly, the most formidable and sophisticated African socialist thinker of all time" (Mohiddin, 1999:4). For Mohiddin, Nyerere's Ujamaa socialism was a result of his effective thinking. In support of Mohiddin, Emma Hunter (2015) contends that Nyerere, through Ujamaa criticism provided a moral philosophy which continues to critique the immoral behaviour (especially corruption) of public leaders in Tanzania and made Nyerere a powerful political metaphor. Here, Hunter associates the continuous adherence to Nyerere by contemporary Tanzanian leaders from all political parties with his ideas on Ujamaa socialism specifically on leadership morals. And like Mohiddin (1999), Hunter also suggests that positive contributions of Ujamaa to Tanzania are the results of Nyerere's effective thinking. Positive contributions of Ujamaa include the increased access of social services especially education following the establishment of primary schools in almost every village and the development of the agricultural sector especially in Mbeya, Iringa, Rukwa and Ruvuma which became four leading regions in production of food crops in Tanzania (Mpangala \& Mawazo, 2015). Also, Ujamaa contributed to the industrial sector's growth by promoting the establishment of manufacturing industries, textile industries, cashew nuts processing industries, sugar industries, and agricultural tools industries in Tanzania.

Another ideal of president Nyerere is being a principled and courageous leader. As Mohiddin (1999) points out, Nyerere did not fear to act on what he believed to be correct. One of the principled and courageous decisions of Nyerere was his order to abandon significant West German aid packages after West German threatened to withdraw the packages if the embassy of East Germany was shifted to Dar es Salaam from Zanzibar, following the Union between Tanganyika and Zanzibar in 1964 (Mohiddin, 1999). Nyerere regarded the West German threat as unwarranted interference in Tanzanian internal affairs. A similar incident was Nyerere's decision to break diplomatic ties with the British Government following the Unilateral Declaration of Independency (UDI) in Southern Rhodesia (Zimbabwe) in 1965. He referred to this "as a matter of the honour of Africa" (7). Also, despite the hostile relationship between Nyerere and Idi Amin Dada of Uganda, when Israel commandoes raided Entebbe airport in Uganda on $4^{\text {th }}$ July 1974, Nyerere publicly "condemned the action as violation of the sovereignty of an African country" (8). Mohiddin implies that Nyerere was able to make the above decisions because he was principled and courageous. Despite being a leader of a poor country, which depends on foreign 
aids and grants, Nyerere was able to challenge donor countries in order to protect the sovereignty of Tanzania and Africa in general.

Msekwa (n.d.) points out that Nyerere the president was also a leader who strongly advocated for human rights protection. Msekwa gives an example of the way Nyerere advocated for the rights of the Sultan of Zanzibar Jamshid bin Abdullah al Said after being overthrown in the $12^{\text {th }}$ January 1964 Zanzibar revolution by giving him a temporary residency in Dar es Salaam, until he moved to England. Despite Nyerere's support for the revolution in Zanzibar and his disagreement with the Sultan's leadership in Zanzibar (Haroub Othman, 1995), Nyerere accepted the host the disposed Sultan in Dar es Salaam after the revolution in what Msekwa refers to as the respect for human dignity. Like Msekwa, Albert Venter and Michele Oliver (1993) contend that Nyerere, like Kenneth Kaunda the former president of Zambia, was an important advocate of human rights. They associate Nyerere's Ujamaa with his intention to protect human rights (Venter \& Oliver, 1993). Venter and Oliver suggest that the aim of Ujamaa under Nyerere was to protect human rights through equality and sharing of resources.

Despite those ideals, as Tundu Lissu -Vice chairman of Tanzania leading opposition part CHADEMA - says, Nyerere was not a saint. There are number criticism against Nyerere and his ideas from different scholars and politicians in and outside Tanzania. This paper brings together criticism against Nyerere in number of areas including his Ujamaa socialism, the union with Zanzibar, his role in building peace in Africa and his position towards Islamic religion in Tanzania. The papers reviews the criticisms and establishes corresponding arguments against or for those criticism.

\section{Methods}

This study involves the review of existing literature about Nyerere. Literature was accessed from the University of Dar es salaam libraries in Tanzania, Makerere University in Uganda and several internet sources. Documents reviewed included journal articles, books, conference papers, memos and newspapers. Data collected include those about Nyerere, Ujamaa, Zanzibar revolution, union between Tanganyika and Zanzibar, Islamic religion in Tanzania, decolonization struggle in Africa etc.

After collecting relevant documents, the researcher coded the data by assigning themes to each relevant document. The literature with related themes were grouped together. Coding and grouping the related literature helped the researcher analyse and present the data according to their relevance to this study's subject matter and the relationship between the data.

The researcher employed content analysis method in analysing and interpreting the data. The content of each selected document were analysed and interpreted accordingly.

\section{Findings and Discussion}

\subsection{General Criticisms}

Despite Nyerere's wide appreciations by domestic and international scholars, Nyerere's ideas, leadership style, and actions are not free from criticism. This section looks at the general criticisms of Nyerere's life and ideas.

According to Brennan (2015), much of the open and direct criticism against Nyerere while still in office came from foreign and exiled Tanzanian critics. Brennan explains that most domestic critics "took the indirect form of subtle and ironic wordplay" (Brennan, 2015:156). Domestic critics feared to criticise president Nyerere openly. Brennan discloses that open and direct criticism against Nyerere came after Nyerere retired in 1985, and after the introduction of the multiparty political system in Tanzania in 1992. Brennan suggests that during the reign of Nyerere, Tanzanians enjoyed limited freedom of expression to the extent that his critics were compelled to use indirect ways such as fiction. In the previous section, we noted that much of the criticisms against Nyerere related to his role in the decolonization of Tanganyika. In the later years of his leadership however, there was increased criticism of performance in relation to democracy in Tanzania, human rights, the Tanganyika and Zanzibar union, Ujamaa socialism (Arusha declaration), poverty and his handling of the Islamic religion.

Johnson (2000:66) provides a general appraisal of the responses to Nyerere's policies, including his role in decolonisation, his devotion to peace, human rights, unity, national development, respect of sovereignty of other countries, and democracy. For Johnson, supporters and critics of Nyerere talk about different things. Whereas Nyerere's critics focus 
on "horror, economic failure, and restraints on individual liberty", supporters talk about "national liberation, national building, and assertions of ideological principles" (Johnson, 2000:66). Johnson's argument above implies that most of criticisms against Nyerere have not been sufficiently refuted since supporters emphasise different issues, contrary to the arguments of Nyerere's critics.

On the decolonisation struggle, Johnson argues that Nyerere who stayed in power longer than other African nationalists and "became a living symbol of the golden era of African nationalism, the era of struggle and victory, of suffering and glory," did less than the others to earn the reputation of a freedom fighter (67). Johnson clarifies that the struggle for decolonisation of Tanganyika did not involve armed struggle or violence, and that Nyerere was not imprisoned; thus "his pass to independence was much smoother than others" (67). Johnson criticises those who glorify Nyerere as a freedom fighter, equating him to or even elevating him beyond Kwame Nkrumah, Jomo Kenyatta, and Milton Obote. For Johnson, Nyerere's role in the decolonisation of Tanganyika is over-exaggerated, since he contributed very little to the struggle of the country, which was already favoured by being United Nation Trust Territory (67-68). This status meant that Tanganyika was on its way to attain its independence even without Nyerere's efforts.

For Johnson, the role of Nyerere in the decolonisation of Southern African countries is another exaggeration. Though Nyerere is considered to have taken a central role in the liberation of South African countries especially South Africa and Namibia, Tanzania (unlike Angola and Mozambique) was not "at a major risk as a result of Nyerere's support of liberation movements" (68). Johnson suggests that Nyerere's risk in supporting liberation movements was small compared to that of Edwardo dos Santos and Samora Machel of Angola and Mozambique respectively. Johnson therefore concludes that "... it was the era of decolonisation that made Nyerere, and not Nyerere that made the era of decolonisation" (69). Johnson's conclusion denotes that though Nyerere is adored for championing the decolonisation, his contribution to the decolonisation era was small. Johnson's criticism downplays Tanzania and Nyerere's role in the decolonisation of southern Africa, because unlike Mozambique whose president Samora Machel was killed during the struggle, Tanzania and Nyerere himself did not suffer a direct military impact from colonialists. ${ }^{1}$ Johnson's contentions ignore Nyerere's military actions like sending soldiers to Mozambique to help Samora Machel, and the opening of training camps for Mozambican, South African and Zimbabwean freedom fighters in Tanzania.

Johnson is also sceptical about the role of Nyerere in building Tanzania. On the example of unity in Tanzania for which Nyerere is widely credited, Johnson argues that "again, this praise seems extravagant. Nyerere did well as a nationbuilder mainly because he did not spoil what was already there - for he was able to build on very favourable foundations" (69). Johnson points out that the tribes in Tanzania are small, thus non fears the other, and that Kiswahili was not created by Nyerere because "Swahili became a lingua franca in what was to become Tanganyika as early as the nineteenth century" (70). Johnson adds that building of unity in Tanzania was not difficult like in Kenya, Uganda or Nigeria. Here, Johnson suggests that Nyerere's work in building unity in Tanzania was simple because the pillars for unity in Tanzania, unlike in Kenya, Uganda and Nigeria were already in existence. For Johnson, Nyerere's strong contribution can only be seen in religious harmonisation because despite being a devoted Christian, Nyerere campaigned for religious tolerance in the nation.

Although Nyerere is widely revered as a pioneer of peace and unity, Johnson also criticises his intervention in other sovereign states, which disrupted peace and unity. Citing the examples of Nyerere's threat to intervene militarily in Burundi when he was a peace mediator, intervention in Uganda in 1978, sending Tanzanian soldiers to Comoros in 1975 and Seychelles in 1977, Johnson criticises Nyerere for not respecting the sovereignty of other African countries. For the Ugandan intervention, Johnson argues that one of Nyerere's grave mistakes was the use of soldiers to re-instate his own friend Milton Obote after evicting Idi Amin, despite the evidence that Obote had become unpopular in Uganda, which led to the eruption of civil war (74). Here, Johnson pays more attention to African states' sovereignty without looking at the reasons that compelled Nyerere to intervene. For example, in Uganda's case, Johnson ignores the arguments that

\footnotetext{
1 "Samora Machel, the first president of Mozambique died on 19 October 1986, in a plane crash on a hillside in Mbuzini in northeastern South Africa. There were only nine survivors among the 44 people on board. It is widely believed that apartheid South Africa engineered the accident by leading the plane off course using a VOR (very high frequency omnidirectional range) signal, a decoy beacon transmitting on the same frequency as Maputo airport, which had a power failure that night. Mozambique, the USSR and the International Civil Aviation Organisation (ICAO) demanded an independent inquiry, but South Africa (which blamed 'pilot error') ignored these demands, and also refused to hand over the black boxes until more than a month after the crash". (Conchiglia, 2017)
} 
Nyerere's intervention in Uganda was intended to protect his country, which Idi Amin had invaded and liberate Ugandans from the dictatorial leadership of Idi Amin (Acheson-Brown, 2001).

Apart from the criticisms against Nyerere reviewed above, Johnson supports the perception that Nyerere was a human being with special qualities. Though most criticisms against Nyerere are real and irrefutable for Johnson, "not even his harshest critics denied that he possessed a certain charisma" (66). Johnson clarifies that "for many, Nyerere still remained "Baba la [sic] Taifa", which means "Father of the Nation", or even broader, "Father of the African Struggle" or "Father of Africa"; and, of course, "Mwalimu" - "the Teacher" (66). The acknowledgement by even his critics that Nyerere had special endowments sharpen our understanding of the psychology behind the mythmaking about Nyerere in various Tanzanian communities.

\subsection{The State of Democracy and Human Rights under Nyerere's Leadership}

According to Kweka (1995), "Tanzania become a one party state with effect from 1965" after Nyerere had successfully persuaded the TANU National Executive Committee of "the need for a one-party system." (66). Nyerere advocated for the one-party system as a way of building and strengthening unity in Tanzania. According to Johnson (2000), Nyerere believed that a single party system under his leadership was the most effective type of democracy in Africa. He is on record as saying that "I really think that I ran the most successful single-party system on the continent" (Johnson, 2000:73). Nyerere stressed that his decision to introduce single party system in Tanzania was appropriate. However, despite Nyerere's strong advocacy for the one-party system, several critics within and outside Tanzania accused the system of suppressing freedom of expression and helping Nyerere suppress his critics and opponents.

One of the strongest criticisms against Nyerere's single party system comes from a Tanzanian, Ludovick S. Mwijage, in the book The Dark Side of Nyerere's Legacy (1994). For Mwijage, Nyerere supressed democracy in Tanzania; the democracy which Nyerere was preaching in his writings and speeches never existed in Tanzania (Mwijage, 1994). Mwijage insists that Nyerere was a hypocrite who campaigned for democracy which he did not practice. Mwijage further argues that Tanzanians under Nyerere lost their liberty and self-esteem, and that though Tanzanians gained their independence from colonialists, they lost their freedom to Nyerere. Mwijage asserts further that "democracy cannot prevail where parliament and the judiciary do not exist as sovereign entities, but are controlled by a single-party dictator" (58) because Nyerere "...exercised power not through institutions but as a single man" (40). Mwijage's arguments above suggest that the single party system enabled Nyerere to monopolise and seize power from other organs of government. For Oscar Kambona (1991), Nyerere's desire to monopolise power in the nation came from his admiration of the Chinese development model, which had been enabled by one man, Mao (19). However as Johnson (2000) suggests, Nyerere's decision to dominate power led to the failure of his plans, policies and ideologies.

During Nyerere's regime the suppression of democracy during Nyerere's regime went hand in hand with the deprivation of human rights, for those who dared to oppose or were suspected of opposing him. In his book, Mwijage documents several incidents which indicate deprivation of human rights under Nyerere's leadership. With reference to abusive conditions to Mwijage and other detainees in Tanzanian cells, Mwijage records that:

Experience is life's best teacher. What I was enduring at one of Nyerere's detention camps was a nasty experience, but it taught me more about the man so much revered the world over as the most "enlightened" and liberal African leader; one who upheld the rule of law and propagated the principles of human rights and equality ... Nyerere often lambasted the white minority South African government for its scant regard for the rights of the black majority. I now started to wonder if the world was aware that Nyerere's frequent condemnation of South Africa's excesses were designed, in part, to deflect attention from his own human rights abuses (38-39).

For Mwijage, the deprivation of human rights under Nyerere was more critical even than British colonialists (39). British rule in Tanganyika showed tolerance and had neither political prisoners nor political refugees (39). On the contrary, as Mwijage witnessed, Nyerere's rule detained many Tanzanians for political reasons while others fled Tanzania and lived elsewhere as political refugees.

According to Mwijage, Nyerere established cells such as Oysterbay in Dar es Salaam and "...Zanzibar's most notorious torture chamber, Kwa Bamkwe, otherwise known as Kwa Mandera..." to torture his opponents (42). Despite the lack of justice and the torture of Nyerere's critics (as Mwijage contends) such as Bibi Titi Mohamed, Michael Kamaliza, Gray Likungu Mattaka, Dunstan Lifa Chipaka and his brother Elia, and Philip Milinga (42), donors continued to support Nyerere without paying attention to the state of human rights in Tanzania. 
Mwijage makes a detailed description of the horrors he went through, starting with being kidnapped from Swaziland where he had escaped to as a political refuge, in an operation jointly carried out by Tanzanian intelligence and their Frelimo allies:

A soldier pushed me with a rifle butt, urging me to keep moving. He ordered me to put my hands above my head and obey all orders. I counted nine soldiers; they were joined by nine more as we started moving towards a nearby Frelimo camp. The new arrivals were harsh, kicking and hitting me with their rifle butts, shouting "bandido", a Portuguese word for bandit, the term used by Frelimo to describe Renamo rebels. Jo suggested to the soldiers that they handcuff me as I was "too smart" and might try to escape.

He then describes the dehumanizing conditions under which he and his fellow prisoners were held:

Detainees being held in the rooms never saw each other, although we all used the same toilet and bathroom. If two internees banged their stools simultaneously, signalling that they wanted to use the toilet, one would be told to wait until the other had finished and been returned to his room. Only then would the second detainee be permitted to go to the toilet.

Mwijage then makes some graphic descriptions of the goings on in one of the government torture chambers in which he was held for several months before he managed to escape. Below is one of the highlights:

Almost every week I could hear the screams of internees being subjected to electric shock torture and beatings; sometimes their pitiful screams carried on throughout the entire night. I could never sleep with torture victims' cries for mercy piercing the night (38).

He then observes:

The human rights situation in Nyerere's Tanzania was compounded by the ambivalence of Western donor countries: they propped up a failed experiment (Ujamaa) with billions of dollars, believing it might work; yet they failed to condemn unequivocally the human rights abuses in Tanzania. Financial support, notably from the Scandinavian countries, ensured the survival of Nyerere's regime; survival which ultimately gave rise to rampant corruption and oppression (39).

Here, Mwijage indicates that despite Nyerere's evils, his image continued to shine among Western donors. In spite of perpetuating acts of torture against his critics, Nyerere skiffully continued to maintain a shining image among the donors.

In addition to several incidents which happened under Nyerere's regime, Mwijage also associates Nyerere with deprivation of human rights in Tanzania after his regime, such as the death of Mousa Membar, a leader of a secret political organization in 1991 during the leadership of President Ali Hassan Mwinyi (48). Associating abuse of human rights in Tanzania with the retired Nyerere highlights Nyerere's persistent influence in the political life of Tanzania, crediting him with the capacity to excise power in perpetuity as long as he lived.

\subsection{Zanzibar Revolution and the Union of Tanzania}

In his paper about the Union between Tanganyika and Zanzibar, Othman (1995) argues that the relationship between Tanganyika and Zanzibar was "one of most persistent problems" which Nyerere faced during his leadership (170). Othman associates the problems that faced the union between Tanganyika and Zanzibar with disparity in the history of Zanzibar and that of Tanganyika from their colonial background and the way they gained their independence (Othman, 1995:170-171). The struggle for independence in Tanganyika was led by TANU as the only powerful political party, and did not have problems of internal rivalry and disunity. On the other hand, there were two parties of near equal strength in Zanzibar: the ASP (Afro-Shiraz Party) and the ZNP (Zanzibar National Party). The ZNP's electoral fortunes were boosted by the alliance with ZPPP (Zanzibar and Pemba People's Party), which had split from the ASP, and it won marginally. But this did not save the government of Sultan Jamshid bin Abdullah al Said from being overthrown in the revolution of $12^{\text {th }}$ January 1964 by the ASP, which had the full support of TANU. According to Othman, the disunity between the Zanzibaris and the support of TANU for the ASP has always made Zanzibar a sensitive nerve in Tanzanian politics, especially during Nyerere's rule, who was the principal architect of the Union.

According to Fouere (2015), most of the criticisms against the union of Tanganyika are linked with the role of Nyerere in the revolution of Zanzibar. Nyerere whose Zanzibaris' critics refer to him as the enemy of the nation (Zanzibar) is challenged for masterminding the revolution of Zanzibar in order "to impose on the islands, the Black African culture of the mainland" (Fouere, 2015:181). Fouere reveals that the overthrow of the Sultan of Zanzibar and the eventual union between Tanganyika and Zanzibar to form Tanzania are perceived by his critics as Nyerere's strategies to dominate 
Zanzibar. To Ali al-Barwani Muhsin (a former leader of ZNP), Nyerere's evils in Zanzibar cannot even be compared to those of Adolf Hitler (Muhsin, 2002:162). Muhsin clarifies that:

Hitler built then destroyed everything by his mania. But this man (Nyerere) is worse ...He has destroyed Zanzibar and all its fine orchards and plantation of cloves and coconut palms (162).

The union of Tanzania as perceived by Muhsin is just a mode through which Nyerere dominated and destroyed Zanzibar. For Muhsin and other Zanzibaris critics, Nyerere's rule in Zanzibar proceeded alongside the deprivation of human rights including arrests, detaining, and torture of Zanzibaris, especially those who criticised the union. Muhsin insists that the union deprived Zanzibaris of their freedom and power.

One of the most recent criticism against Nyerere's role in the union comes from a vice chairperson of the leading opposition party in Tanzania, CHADEMA, Tundu Lissu. Responding to accusations that he had insulted Nyerere during the special parliament for constitutional change (Bunge Maalumu la Katiba), Tundu Lissu - then attorney general of CHADEMA and a member of Parliament of the United Republic of Tanzania - argued that Nyerere made some critical mistakes since he was not God, not an angel and even he is not yet a saint, and that criticising him is to demonstrate that he was a human being (TBC1, 2014).

Tundu Lissu criticises Nyerere for using his lawyers to forge the signature of Abeid Aman Karume, the first president of Zanzibar on the Union Treaty. According to Tundu Lissu, the actual Union Treaty never existed and that the union does not exist in reality because Zanzibar has never lawfully endorsed it (TBC1, 2014). This implies that Nyerere formed a fake union between Zanzibar and Tanganyika. Fouere (2015) asserts that the original document of the Union Treaty "which needed to be signed by both sides to be valid, does not exist or that Karume did not sign it. ... the agreement was neither validated by members of the government nor the then attorney general Wolfgang Dourado" (185). Similar to Tundu Lissu, Fouere's contention indicates that the union does not legally exist because Zanzibar did not legally endorse it. Both Tundu Lissu and Fouere's arguments denote that Nyerere pushed Zanzibar into the union which they themselves never consented to, and eventually seized their sovereignty.

Criticisms against Nyerere with respect to his role in the revolution of Zanzibar and the union of Tanzania are to a large extent associated with disunity among the people of Zanzibar since the colonial era. The criticism against Nyerere reviewed above strongly demonstrates that there is a group of ZNP/ZPPP-leaning Zanzibaris who did not support the revolution in Zanzibar. By supporting the revolution, Nyerere appeared to support ASP over the other political parties. As a result, the act of uniting Zanzibar and Tanganyika few months after its critics regard the revolution as Nyerere's intention to secure the revolution and strengthen the rule of ASP in Zanzibar. To these critics, Nyerere is an invader who used the revolution and the union to decide who would rule Zanzibar.

\subsection{Ujamaa Ideology and Poverty}

Nyerere's peculiar socialist ideology famously known as Ujamaa is among the things that made Nyerere renowned throughout the world. As discussed earlier, Nyerere introduced Ujamaa in Tanzania in order to achieve development of the country through self-reliance and citizen cooperation. Venter and Olivier (1993) define Ujamaa as "a family relationship of a spirit of cooperation and equality, as well as a preparedness for mutual aid and the sharing of possession" (24). According to Mpangala and Mawazo (2015), Ujamaa was the ideology founded with the intention to promote equality, community ownership of means of production, wealth sharing and a self-reliant-economy. Nyerere's implementation of Ujamaa was intended to promote human rights in the country and make sure that everybody in the country accessed education, health facilities, food and drinks (Mohiddin, 1999; Hunter, 2015; Mpangala and Mawazo, 2015). To Cornelli (2012) "Ujamaa offered an alternative way of life, a life that rejects evils such as racism, exploitation, slavery, colonialism, and slave trade and embraces the good, such as freedom, equality in terms of rights and opportunities, and tolerance" (235). However, the ideology is among the things for which Nyerere is highly criticised throughout the world (Brennan, 2015). With reference to Brennan, foreigners such as Shiva Naipaul a Trinidadian criticised Nyerere's brand of socialism as a failure. For Naipaul, socialism in Tanzania was "being built in words" (Brennan 2015:156). Naipaul does not however directly criticise Ujamaa as an ideology; rather he criticises Nyerere's regime for failing to properly implement the ideology in order to reach its predetermined goals. Naipaul's argument suggests that Ujamaa would have benefited Tanzania if the plans had been properly implemented.

For Antony Daniels, a British psychiatrist, Ujamaa ideology made Tanzanians poor (Brennan, 2015:144). Daniels describes Nyerere whose honorific title was "Mwalimu (Teacher) as certainly a Professor of Poverty" (as cited in Brennan, 2015:144). Here, Daniels implies that Nyerere with his Ujamaa ideology made his country and people poor. Contrary to 
Naipaul, Daniels criticises Nyerere for adopting a wrong ideology which left Tanzanians with high levels of poverty. However, according to Johnson (2000), Nyerere believed that criticising Ujamaa because of poverty was wrong. For Nyerere, "Tanzania's problem was not socialism but poverty" (73). Nyerere's contention indicates that Tanzania would have the low level of economic prosperity even if it did not implement Ujamaa ideology. To him as Njozi (2010) reports, despite its failure, Ujamaa was not a bad ideology.

Among the leading critics against Nyerere and Ujamaa is Oscar Kambona, a former foreign minister of Tanzania and former friend to Nyerere. According to Kambona, who conflicted with Nyerere over Ujamaa and fled to London in 1967, Nyerere imposed Ujamaa hypocritically because he was secretly accumulating wealth for his own family (Brennan, 2015:163-164). Kambona criticised Nyerere for owning a "luxurious international hotel with a swimming pool and sauna bath ... at the so-called Butiama Ujamaa village, and that Joseph his brother gets a salary of 7000 shillings, which makes him the second highest paid" person in Tanzania next to president himself" (as cited in Brennan, 2015:164). For Kambona, Nyerere who imitated socialism from China did not abide himself on socialist requirements, but he used it to exploit resources. Like Daniel's, Kambona's contentions suggest that Ujamaa was an inappropriate ideology, and accused Nyerere of introducing into the country an ideology which he himself did not believe in, and consequently impoverished Tanzanians.

For most of the critics against Nyerere's Ujamaa, the stagnating level of Tanzania's economic development is an indicator that Ujamaa was an ineffective ideology. Unlike Venter and Olivier (1993) who regard Ujamaa as "a family relationship of a spirit of cooperation and equality, as well as a preparedness for mutual aid and the sharing of possession" (24), other critics consider Ujamaa as an economic ideology primarily intended to enhance economic development to the nation. Therefore to the critics, the failure of Nyerere's Ujamaa to liberate Tanzania economically is evidence that it was an inappropriate ideology.

\subsection{The State of Islamic Religion under President Nyerere}

S. J. Warioba (2004) (the former Prime Minister of Tanzania) suggests that Nyerere "... was a passionately religious man who respected his superiors. As a political leader, he did not allow his religious beliefs to influence his political views and actions" (19). And Yoweri Museveni, the president of Uganda asserts that Nyerere's religious belief did not influence his views and actions as a political leader. For Museveni, as explained earlier, "Tanzania is a country of Christians, Muslims and animists but Mwalimu (Nyerere) was able to unite them by demonstrating that they are all children of God" (as cited in Mesaki \& Malipula, 2011:98-99). Nyerere himself affirms that "every citizen has the right to freedom of expression, of movement, of religious belief, and of association within the context of the law" (Julius K. Nyerere, 1977:3). However, despite his own claims, despite the fact that he is widely credited with uniting Tanzanians regardless of their different ethnic and religious backgrounds (C. K. Omari, 1995; Mesaki \& Malipula, 2011), there are those that strongly criticize him for discriminating against Muslims in Tanzania.

Mohamed Said's The Life and Times of Abdulwahid Sykes (1924-1968): The Untold Story of the Muslim Struggle against British Colonialism in Tanganyika (1998) is one of those works that are highly critical of the way Nyerere treated Muslims in Tanzania. Said (1998) argues that the decolonization struggle in Tanganyika (Tanzania Mainland), for which Nyerere is widely credited, was actually initiated and strongly reinforced by Muslims. Said provides what he calls the unrecorded history of the political struggle for decolonisation of Tanganyika. This history begins with the African Association (AA), and later the Tanganyika African Association (TAA), which was finally transformed in 1954 to form TANU, the party which under Nyerere led Tanganyikans to independence on $9^{\text {th }}$ December 1961. According to Said, the African Association was formed in 1929 by a Muslim called Kleist Sykes (South African Zulu by origin), a Tanganyika Railway's typist who formerly served as a soldier under Germany in World War 1, together with his fellow Muslims such as Mzee bin Sudi, Ibrahim Hamis, and Said Mpima (Said, 1998:40-41). These were inspired by Ghanaian scholar Dr James Kwegyir Aggrey who visited Tanganyika in the year 1924. Said argues that British colonial rulers in the then Tanganyika, with the support from missionaries, warned Christians against joining the African Association, which made the party mainly register Muslim members. Apart from some tribal uprisings against colonial rule, such as the Maji Maji war of 1905-1907, the formation of African Association marked the beginning of the organised political struggle against colonialism.

Said elaborates that Muslims led the African Association's transition to TAA and later to TANU under Kleist Sykes, and later under his son Abdulwahid Sykes. According to Said, Abdulwahid Sykes initiated the actual political struggle for decolonisation by establishing and leading what was known as TAA Political Subcommittee in 1951 together with Sheikh Hassan bin Amir who was the Mufti of Tanganyika and others. The committee transformed the TAA from a welfare association into a political organisation (88-98). The involvement of the Mufti of Tanganyika in TAA political subcommittee 
activities signifies direct involvement of Muslims in the liberation struggle. Said reveals that Abdulwahid Sykes invited Nyerere to join TAA after Nyerere was introduced to him by Kasella Bantu. Bantu was a very radical politician who was also a close friend to Nyerere but later become his critical opponent (110). Said further reveals that Abdulwahid Sykes, with his fellow Muslims such as Ally Sykes (his young brother) and Dossa Aziz, left the leadership of the TAA and later TANU to Nyerere, because Nyerere was highly educated and had admirable debating skills. Said suggests that Nyerere would not have become the leader of the liberation struggle in Tanganyika if it was not for the Muslims to give him that leadership opportunity.

Despite the long list of Muslims who sacrificed their time, families and wealth to liberate Tanganyika, and even though the number of Muslims in Tanganyika was higher than that of other religious denominations, Said contends that after independence Nyerere's government deliberately ignored and undermined Muslims in power sharing. Said argues that Nyerere not only ignored the role of Muslims in the liberation struggle, he also deliberately forgot the position of Abdulwahid Sykes in TAA (115); and yet this is the man, according to Abdallah Mohamed (Said's uncle), "... who formed TANU and would have become the president of this country [Tanganyika] if he had wanted to" (Said, 1998: xxiv). The act of Nyerere forgetting about the position of Abdulwahid Sykes in the struggle against colonialism signifies his deliberate intention to devalue the role of Muslims in the liberation struggle.

In addition, Muslims were arrested and detained under Nyerere's regime, and their organisations including the Tanzanian branch of the East Africa Muslim Welfare Society (EAMWS) whose objective was to promote Islam in East Africa, were suppressed (282-302). For Said, the formation of BAKWATA-Baraza Kuu la Waislamu Tanzania (the National Muslim Council) instead of EAMWS by Nyerere's regime was to accommodate Muslims who Said refers to as traitors. Said clarifies that, "to refer to a Muslim as a BAKWATA member is like calling a Christian a disciple of Judas Iscariot, who betrayed Jesus for thirty pieces of silver" (303). This suggests that Nyerere instigated disunity between Muslims in Tanzania.

In his book Freedom and Unity/Uhuru na Umoja: A Selection from Writings and Speeches 1952-1965 (1966), Nyerere implicitly accepts accusations of discrimination against Muslims in Tanzania, especially in terms of employment opportunities, which resulted from education differences between Christians and Muslims (179). Nyerere clarifies that employment in current society depends mostly on levels of education, and that Christians are more educated than Muslims (Nyerere, 1966). Nyerere admits that some Muslims resent the act of giving Christians higher positions in his government. However, he justifies the discrepancy as inevitable because Muslims lacked the appropriate levels of education. Nyerere rejects accusations of religious discrimination, and seems to imply that Muslims should blame themselves for not acquiring the acceptable levels of formal education on which nominations for top government positions were based.

Nyerere's denial of religious belief-based discrimination notwithstanding, Fouere (2015) indicates that Said's contentions continue to receive support in contemporary Tanzania. Fouere reports that the works of Said and Harith Ghassany (which also criticises Nyerere for his role in the Union of Tanzania and the status of Muslims in Tanzania) continues to be reprinted weekly in a Muslim newspaper, An-Nuur (Fouere, 2015). The continuing spread of Said's criticisms against Nyerere indicates the support of Muslims for Said's arguments. After the 2010 general election in Tanzania, the newspaper An-Nuur covered criticisms made by Mainland Muslims against what they referred to be Mfumo Ukristo (Christian system) in Tanzania. Muslims criticising the Tanzanian government for perpetuating a Christian system signifies the support of Said's suggestion that Christians were more favoured in the country. With reference to Fouere, the beatification process to make Nyerere a saint by the Catholic Church is interpreted by Muslim critics in Tanzania "as the reward of the advantages Nyerere granted to the Church in his lifetime and his fight against the power and spread of Islam" (189). Here, Fouere suggests that to Muslim critics, Nyerere successfully discouraged the growth of Islam in Tanzania.

In his book Muslims and the State in Tanzania (2010), Njozi asserts that Nyerere contributed to the discrimination and harassment of Muslims even in the contemporary Tanzania. According to Njozi, Nyerere promised Muslims before independence that the question of imbalance especially in education would be solved after independence (Njozi, 2010). Njozi contends that the problem of educational imbalance between Muslims and Christians in Tanzania was created by colonialists. As opposed to Germans who mostly favoured Muslims, British colonialists in Tanganyika favoured Christians. In order to solve the imbalance created by British colonialists, Njozi argues that Muslims under All Muslim National Union of Tanganyika (AMNUT) urged the colonial government to delay the independence of Tanganyika until Muslims acquired education similar to Christians. However, Nyerere argued that since British colonialists are responsible for initiating the discrimination against Muslims, they could not be expected to solve the problem of imbalance (15). As a result, Nyerere promised Muslims that the problem could only be solved after independence (15). But, despite Nyerere's declaration in 1985 that he had succeeded to remove religious imbalances in Tanzania, Njozi argues that "Muslims claim, with strong 
evidence on their side, that the solemn pre-Independence promise has not been kept" (17). Njozi stresses that since independence the government of Tanzania works in favour of Christian churches.

As Njozi points out, Christian churches in Tanzania hold political power by which they influence and persuade the government to favour Christians and suppress Muslims. As he points out, "political power is a slow-flowing river. Of course, a river can once in a while become capricious, burst its banks and chart out a new course" (37). Here, Njozi associates the power which Christian churches have and the suppression of Muslims in the contemporary Tanzania with Nyerere's failure to fulfil his promise to solve the Muslims' question of discrimination since independence (15-17). According to him, Nyerere's decision to ignore the Muslim question enabled Christian churches to accumulate power which they now use to dominate Muslims and suppress Islam.

Muslims in Tanzania, as Njozi contends, are discriminated in education, political appointments and employment. Njozi adds that Christian churches with the help of Christian government officials use the government machinery such as police and High Court of Tanzania to harass Muslims and suppress their rights including the right to worship the Almighty God $(21-25,31,51)$. Njozi uses killings of several Muslims at Mwembechai mosque in Dar es Salaam on $13^{\text {th }}$ February 1998 as an example of deliberate actions planned and implemented under the command of Christian police officials to kill and harass Muslims in Tanzania (80-85). On the side of the High Court, Njozi provides the example of the High Court ruling of $24^{\text {th }}$ August 2001 with regard to Hamis Rajabu Dibangula's case who was arrested for uttering in public that "Jesus is not son of God" and that "anyone who says that Jesus is the son of God is a disbeliever" (22) to stress on the use of government machinery in favour of Christian churches. According to Njozi, the High Court ruled that Dibangula's case was a minor offence and that the 18 months sentence he earlier received from District Court of Morogoro was supposed to be not more than 12 months. Njozi contends that the ruling, which was later nullified by the Court of Appeal of Tanzania on $14^{\text {th }}$ March 2003, was dangerous because it denied Muslims the right to preach their religious beliefs. To him, Muslims are facing those challenges because Nyerere, his party CCM and later leaders in Tanzania did not only ignore the problem of discrimination of Muslims in Tanzania but also favoured/favour Christian churches in a number of ways including using public funds to finance church-owned services such as health services.

In general, criticisms against Nyerere with respect to religious discrimination in Tanzania are based on the fact that the struggle for decolonisation in Tanganyika was led by Muslims but the top administrative posts in post-independent Tanzania were given mostly to Christians. Also, Nyerere's intention to separate politics and religion and suppress political religious groups which mostly were Islamic with the argument of propagating unity in Tanzania is/was seen by Muslims as deliberate efforts by Nyerere-led Christians to undermine the voice and position of Muslims in Tanzania. According to Muslim critics, even TANU as reviewed above was almost a Muslim political organisation, thus separating religion from politics entailed suppression of Muslims in Tanzania politics to create a wide opportunity for Christians to dominate TANU (later CCM) and Tanzanian government. Despite Said and Njozi' criticisms against Nyerere, Yahya-Othman (2020) contends that "Nyerere was equally open-minded about Islamic practices" and that, though "on the rare occasions", he admitted Muslims significant contributions to the independence struggle (6). Also, it is on record that he did appoint several Muslim ministers in his cabinet including two Muslim Prime Ministers (Rashidi Mfaume Kawawa (1972-1977) and Salim Ahmed Salim (1984-1985)); and in 1985, he handed over his presidential position to a Muslim Ali Hassan Mwinyi (Johnson, 2000; Ochieng, 1999). But to the Muslim critics, these were nonetheless Muslim individuals in a dominant Christian government structure.

\section{Conclusion}

A close examination of the history of Nyerere in this paper reveals one important characteristic of Nyerere. In the literature of both supporters and critics, it is suggested that Nyerere was a special person. To his supporters, Nyerere was endowed with special abilities, including intelligence, persuasive powers, courage and wisdom. Consequently, his supporters attribute the success of the liberation struggle, unity, peace and the stability of the union of Tanzania to his special endowments. Even his critics admit that despite his weaknesses, Nyerere was a gifted person. His charisma, debating skills and ability to influence others are difficult to deny. The negative criticism, including deprivation of human rights and democracy, seizure of the freedom of Zanzibar, and undermining Muslims in Tanzania are easily overlooked by his supporters because there was plenty else to say about him. The general belief that Nyerere was special has generated a mythmaking process about him in Tanzania, to the extent that there are those that regard him as a demigod. 


\section{Acknowledgement}

For this paper, I would like to acknowledge Gerda-Henkel Foundation and the Makerere University College of Humanities and Social Sciences for funding the researcher's PhD studies from which this paper emerged. Also, the University of Dar es Salaam for providing to the research fund and covering the researcher's travelling expenses. Special gratitude goes to my university supervisors, Prof. Abasi Kiyimba and Doctor Benge Okot for their guidance and mentorship.

\section{References}

Acheson-Brown, D. G. (2001). The Tanzania Invasion of Uganda: A Just War? International Third World Studies Journal and Review, $121-11$.

Brennan, J. R. (2015). Julius Rex: Nyerere through Eyes of His Critics. In M. A. Fouere (Ed.), Remembering Nyerere in Tanzania: History, Memory, Legacy (pp. 143-169). Dar es Salaam: Mkuki na Nyota Publishers Ltd.

Conchiglia, A. (2017). Was Mozambique Air Crash an Assassination?: The Mysterious Death of Samora Machel. Le Monde Diplomatique. Retrieved from https://mondediplo.com/2017/11/12Machel website:

Cornelli, E. M. (2012). A Critical Analysis of Nyerere's Ujamaa: An Investigation of its Foundations and Values. (Doctor of Philosophy), The University of Birmingham.

Fouere, M.-A. (2015). Recasting Julius Nyerere In Zanzibar: The Revolution, the Union and the Enemy of the Nation. In M.-A. Fouere (Ed.), Remembering Nyerere in Tanzania: History, Memory, Legacy (pp. 171-195). Dar es Salaam: Mkuki na Nyota Publishers Ltd.

Hunter, E. (2015). Julius Nyerere, the Arusha Declaration, and the Deep Roots of a Contemporaary Political Metaphor. In M. A. Fouere (Ed.), Remembering Nyerere in Tanzania: History, Memory and Legacy (pp. 73-94). Dar es Salaam: Mkuki na Nyota.

Kambona, O. (1991). The Time I Met Mao. Salisbury Review, 19.

Kweka, A. N. (1995). One-Party Democracy and the Multi-Party State. In C. Legum \& G. Mmari (Eds.), Mwalimu: The Influence of Nyerere (pp. 61-79). Dar es salaam, London, Trenton: Britain-Tanzania Society in association with James Currey, Mkuki na Nyota, Africa World Press.

Mesaki, S., \& Malipula, M. (2011). Julius Nyerere's influence and legacy: From a proponent of familyhood to a candidate for sainthood. International Journal Of Sociology And Anthropology, 3(3), 93-100.

Mohiddin, A. (1999). The Mwalimu Julius Kambarage Nyerere: A Distinguished African Statesman an African Giant, amongst Global Giants a Token Tribute. Présence Africaine, Nouvelle série(160 ), 3-13.

Muhsin, A. a.-B. (2002). Conflict and Harmony in Zanzibar. Memoirs. Dubai: (self-published).

Njozi, H. M. (2010). Muslims and the State in Tanzania. Dar es Salaam: Dar es Salaam University Muslims Trusteeship (Dumt).

Nyerere, J. K. (1977). Ujamaa: Essays on socialism. Dar-es-salaam: Oxford University Press.

Nyerere, J. K. (1966). Freedom and Unity/Uhuru na Umoja: A Selection from Writings and Speeches 1952-1965. Dar-esSalaam: Oxford University Press.

Ochieng, P. (1999). Mwalimu Nyerere's bequest to Mkapa a tall order. Nyerere 14th October 1999: Press coverage from the Internet, pp. 28-30. https://www.juliusnyerere.org/resources/P21

Omari, C. K. (1995). The Management of Tribal and Religious Diversity. In C. Legum \& G. Mmari (Eds.), Mwalimu: The Influence of Nyerere (pp. 23-31). London, Dar es salaam, Trenton: Britain-Tanzania Society in association with James Currey, Mkuki na Nyota, African World Press.

Othman, H. (1995). The Union with Zanzibar. In C. Legum \& G. Mmari (Eds.), Mwalimu: The influence of Nyerere (pp. 170-175). Dar es salaam, London, Trenton: Britain-Tanzania Society, Mkuki na Nyota, Africa World Press, James Currey. 
Said, M. (1998). The Life and Times of Abdulwahid Sykes (1924-1968): The Untold Story of the Muslim Struggle against British Colonialism in Tanganyika. London: Minerva Press.

TBC1 (Producer). (2014). Kamati ya maridhiano six: Mhe. Tundu Lissu. Retrieved from https://m.youtube.com/watch?v=4Yvp

Venter, A., \& Olivier, M. (1993). Human Rights in Africa: Nyerere and Kaunda. International Journal on World Peace, 10(1), $21-33$

Warioba, S. J. (2004). Principles of National Unity in Tanzania The Commemoration of Mwalimu Julius K nyerere 79th and 80th Birth Dates (pp. 16-23). Dar es Salaam: Mwalimu Nyerere Foundation. 